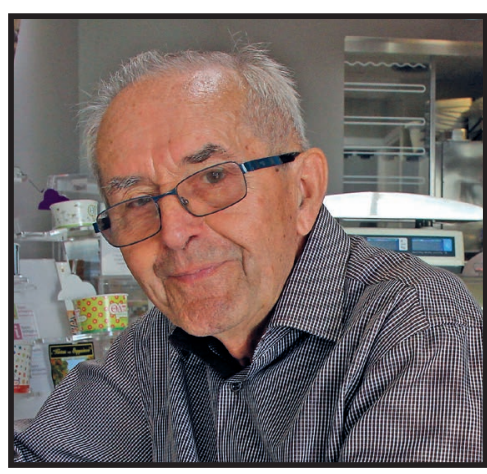

\title{
Elhunyt Szajkó István gyémántdiplomás hadmérnök (1932-2020)
}

Életének 88. évében, 2020. március 16-án elhunyt Szajkó István fejlesztőmérnök, lőszertervező, ballisztikai szakértő. Szajkó István 1932-ben született Szekszárdon. 1957-ben a Budapesti Műszaki Egyetem Hadmérnöki Karának ipari szerves kémia tagozatán szerzett kitűnő minősítésű oklevelet. (2017-ben átvehette a Műegyetem gyémántdiplomáját.)

1958-tól a Nitrokémia Rt. Ballisztikai Osztályának kutatómérnökeként lőporok, sújtólég-biztos robbanóanyagok, rakéták szilárd hajtóanyagainak tervezésével foglalkozott. A következő évben a Nitrokémia Ballisztikai Laboratóriumának vezetője lett - amelyet több mint három és fél évtizeden át irányított - és megbízást kapott a Fizikai Laboratórium vezetésére is. Nyugdíjba vonulása után 1997-ig lőpor-marketinggel foglalkozott. Elévülhetetlen érdemeket szerzett a lőporok, lőszerek korszerűsítése területén. Életművéért a vállalattól 1997-ben Szabó Kornél díjat vehetett át.

Fejlesztőmérnökként kutatási feladatai között szerepelt a lőporok és robbanóanyagok tervezése, minősítése; fénymérés, detonációsebesség-mérés, meteorológiai mérések. Nevéhez kötődik többek között az 57 mm-es SZ-60-as légvédelmi ágyú $57 \times 348$ mm-es SR lőszerében használt lőpor, valamint a 7,62 mm-es AMP gépkarabély rakéta-póthajtásos puskagránát hazai hajtóanyag-fejlesztése. Vezető szerepet töltött be a 82-mm-es aknavető gránátjának megnövelt hatótávolságú (nyújtott) lőportöltetének kifejlesztésében. Orosz kutatókkal együttműködve tanácsadóként dolgozott a kiskaliberű Kalasnyikov gépkarabélyhoz készült töltény $(5,45 \times 39$ mm-es) lőporának fejlesztésében is.

A rakéták vizsgálata során felfedezte, hogy a tolóerő talajra gyakorolt hatása olyan rezgéseket kelt, amelyek a geodéziai kutatásoknál is (pl. olajkeresés) felhasználhatók. Ennek alapján „Szilárd sugárhajtóanyagú, szeizmikus rezgéskeltő berendezés" című beadványa 1970-ben szabadalmi védelmet kapott. A kifejlesztett szeizmikus rezgéskeltő berendezést azóta is használják.

Tagja volt a Nemzetközi Polgári Kézilőfegyverek Vizsgálatára létrehozott Állandó Bizottságnak. 1971-ben állami megbízást kapott a kézilőfegyverek vizsgálatának kölcsönös elismeréséről szóló egyezmény Magyarországot képviselő delegáció tagságára (Brüsszeli Egyezmény, C.I.P.). A delegáció aktív tagjaként részt vett a műszaki albizottságok és munkacsoportok munkájában, közöttük az „Acélsörét" munkacsoportban. A személyéhez kötődik a C.I.P. lőszervizsgálati eljárásainak teljes reformja. A C.I.P-ben és munkacsoportjaiban napjainkig aktívan dolgozott.

Szajkó István nem csupán fejlesztőmérnökként, hanem gyakorló sportlövőként és vadászként is folyamatos kapcsolatban állt a fegyverekkel, lőszerekkel. A katonai fejlesztések mellett vadász- és sportlőszerek lőporainak tervezé- sével is foglakozott. Az általa tervezett és a Nitrokémia által gyártott lőporral még olimpiát is nyertek. A sportlövészetet akkor kezdte tanulmányozni, amikor munkahelye megbízta egy új, modern sportlőtér tervezésével. Ezt követően megalakult a Nitrokémia koronglövő klubja, amelynek 1971-ig technikai vezetője, majd 1997-ig elnöke volt. Sportlövő edzői képesítését 1978-ban kitűnő minősítéssel szerezte a Testnevelési Főiskolán. 1976-2000 között tagja volt a Magyar Sportlövő Szövetség Elnökségének, 1992-től a koronglövő szakág vezetőjeként, az edzőbizottság elnökeként tevékenykedett. A Veszprém Megyei Sportlövő Szövetségnek 1972-2004 között elnöke, majd főtitkára volt. Munkásságáért az elsők között részesült Esterházy Miksa díjban.

A Nitrokémia Vadászati Társaságba (Veszprém megye, Tüskevár) 1959-ben vették fel. 1961-től 1996-ig volt a társaság titkára. A Pápai Korona Vadásztársaságban 199397 között töltötte be az elnöki posztot. A Német Vadász- és Sportfegyver Kutató- és Vizsgálóintézettel (DEVA) fenntartott szakmai kapcsolata nyomán több német szaklap jelentette meg cikkeit.

Hivatásának élő fejlesztőmérnökként az oktatói munkába is bekapcsolódott. Megszervezte a hazai vegyipari szakmunkásképzést, ezzel hosszú évekre biztosította a szakember-utánpótlást. Oktatói képességeit kamatoztatva, bekapcsolódott a vadőrképzésbe is, mellettük fegyverműszerészeket és puskaműveseket tanított.

Szajkó István neve saját szakterületén a külföldi és a hazai felsőoktatásban is jól ismert. Számos külföldi és magyar egyetem - pl. a Magdeburgi Műszaki Egyetem, a német Fizikai Technikai Szövetségi Intézet, a BME Gépészmérnöki Kara, az ELTE Geofizikai Intézete - kutatóival folytatott együttműködést. 1995-től közel tíz éven át lőporgyártást és ballisztikát tanított a Budapesti Műszaki Egyetem Gépészmérnöki Kar Gépgyártástechnológia Tanszékén. A Nemzeti Közszolgálati Egyetemen meghívott előadóként előadásokat tartott a Hadtudományi és Honvédtisztképző Kar Haditechnika Tanszékén a fegyverzettechnika specializáció tisztjelöltjeinek. Több mint száz hazai és nemzetközi folyóiratcikk és írásmű szerzője. A Polgári Kézilőfegyver és Lőszervizsgáló Kft.-nél folyó munkát szakértőként, illetve tanácsadóként idős korában is segítette, haláláig aktívan dolgozott. Kiemelkedően eredményes szakmai tevékenységét 1997-ben Eötvös Lóránd-díjjal ismerték el, munkásságáért 2007-ben a Magyar Köztársaság Ezüst Érdemkeresztjét vehette át.

Emlékét megőrizzük.

(Zentay Péter, Kalmár Ödön, Sebők István) 